\title{
THE CHARACTERIZATION OF THE MAIN CHARACTER IN GONE GIRL FILM
}

\author{
* Cindy Putri \\ $* *$ EliaMasaGintings \\ ** Meisuri
}

\begin{abstract}
This article deals with the characterization of the main character in Gone Girl film. The study was aimed to find outthe characterizations and the most dominant characteristic of Amy Elliot Dunne in thefilm. The study was conducted by applying descriptive qualitative method. The data of the study were taken from all utterances of Amy's dialogues and monologues which were transcribed into 39 selected sentences. The findings of the study were: (1) the kinds of Amy characterizations: intelligent(17.94\%), perfectionist $(12.82 \%)$, insecure $(28.20 \%)$, liar $(33.33 \%)$ and vengeful( $7.69 \%)$; $(2)$ the most dominant characteristic of Amy was $\operatorname{liar}(33.33 \%)$.
\end{abstract}

Keywords: characterization, characteristic, main character, film. 


\section{INTRODUCTION}

Nowadays many people love watching films. This phenomenon can be seen from the number of people coming to the cinema. This is due to the fact that watching film is enjoyable and entertaining. Many people enjoy fictional stories whether in the form of films or novels. A film creates an illusion that what occurs on the screen is an objective recording of events. A film has become part of that extensive cultural system of constructions that represent social reality (Klarer, 2004:76).

A film describescharacters who considered as one of the psychological aspects in the story. Characters give the important roles to make the story in a film more alive (Pope, 2005:86). They give the story a purpose, a reason for the audience to care what happens in the film. Especially for the main characters, they have an important role in films. They have big influence to represent the important thing that a film wants to deliver to the audience. Character and personality have a close relationship. In any drama, personality plays a vital role in character's behaviors and actions to protect personal entity and psyche (Charters, 2011:34).

Characterization is the method to analyze the main character's development and personality which deals with the process of creating an image of person in fiction complete with the person's traits, features and motivations (Aquino, 1976:112). It broadly refers to the description and development of character. There are two different approaches to characterization, including direct characterization and indirect characterization. Direct characterization is used when the author tells the audience what the personality of the character is and it is usually used in novel. Indirect characterization used when the author shows things that reveal the personality of the character while it usually is used in film. There are four different methods of indirect characterization: 1) speech, 2) thoughts, 3) action, and 4) looks (Burroway, 2000:52).

This research focused on characterization and the most dominant characteristic of the main character in film reflected by the main character. The writer chooseGone Girl film because it portrayed the actual symbolic of reality. 
This film was about the couple of "Fight Club" who hurt each other where the dominant was Amy as the main character in this film. As a woman, Amy had been forced to embody a succession of female stereotypes, but she twisted it in order to get her own way. She did some manipulation, forgery, and identity changing to trap her cheated husband, Nick Dunne. She manipulated her own murder to push her husband to the jail. It was so interesting to discuss about the characterization of Amy and how she interacted with other characters in the film. The objectives of the study wereto find out the kinds of characterizations and the most dominant characteristic of Amy's in Gone Girl film based on indirect characterization method proposed by Burroway.

\section{REVIEW OF LITERATURE}

\section{Characterization}

Characters are the product of characterization that is to they have been made in particular way. The kind conversation they have, the thing they do, their appearances and so on are the particular ways in which the author has chosen to characterizehis or hercharacter. Character creation is the art of characterization what the author does to bring a character to life to provide the reader with a sense of that character's personality to make that character unique. In other words, characterization is a method while character is a product of the method. Aquino (1976:32) states that characterization was brief but concise. It iscoming from descriptions by a future being of past people and,events, seemingly observed from a great height.

Characterization in literature is the process of authors used to develop character and create images of the characters for the audience. In the other hand, it is a way in which the author revealed his character in a work of fiction or in another word characterization method of character portrayal (Bennett and Royle, 2004:65). In addition, it is very helpful to analyze the main character's development. There are two different approaches to characterization, including direct characterization and indirect characterization. 


\section{a. Direct Characterization}

In direct characterization, the author literary tells the reader what he or she wants us to know about the character. This isdone via the narrator, another character or by the character of him or herself. Direct characterization usually used in novel. Itconsists of the narrator telling the reader about the characters. In addition, Charters (2011:58) states that it can also involve other external details, such as names or other overt commentary.

b. Indirect Characterization

In indirect characterization, the author shows us things about the character to help us to understanding the character's personality and his/her effect on other characters. It usually used in film. Characterization in film is different in novel because film is a visual story telling that the characterization of a character in film more complicated and details than in a novel. Burroway (2000:54) established four different methods of indirect characterization in literary work: 1) speech, 2) thoughts, 3) action, and 4) looks. The differences among themisshowed by the table as follow:

Table. 2.1 The Method of Indirect Characterization

\begin{tabular}{ll}
\hline Speech & $\begin{array}{l}\text { What does the character say? } \\
\text { How does the character speak? }\end{array}$ \\
\hline Thoughts & $\begin{array}{l}\text { What is revealed through the character's private } \\
\text { thoughts and feeling? }\end{array}$ \\
Action & What does the character do? \\
& How does the character behave? \\
Look & What does the character look like? \\
& How does the character dress? \\
\hline
\end{tabular}

\section{Character}

Character can be defined as someone in a literary work that has identity which is made up by appearance, conversation, action, name and thoughts on in the head. Bennett and Royle (2004:60) state that characters are the life of literature: they are the objects of our curiosity and fascination, affection and dislike, admiration and condemnation. A character always uses the tools of communication to interact with other characters. His/her dialogue between 
characters forms a medium between their actions and thoughts. How they communicate with other characters can establish how they feel and described such as where they come from and their relationship with the character to whosethey are speaking.

\section{Personality of character}

Personality has a close relationship with character in literary work even in real life. Millon, et al (2004:2) state personality is seen as a complex pattern of deeply embedded psychological characteristics that are expressed automatically in almost every area of psychological functioning. Additionally, Millon and Everly (1985:4) states that personality represents a pattern of deeply embedded and broadly exhibited cognitive, affective, and overt behavioral traits that persist over extended periods of time.

\section{Types of Character}

Pope (2005:133) suggests thatthere are two categories of character; (a)major character is an important figure at the centre of the story's action or theme. The major character is sometimes called a protagonist whose conflict with an antagonist may spark the story's conflict; (b) minor character is a character that support the major character, the function of it is to illuminate the major character.

\section{a. Major Character}

The major character is called a Protagonist whose conflict with an Antagonist may spark the story's conflict. Protagonist is the major character with whom generally sympathize. The antagonist is the character or force against which the protagonist struggles (Pope, 2005:134). A major character is a character that is emphasized to tell the story. The major character always appears in most of the story, either as subject or as object.

\section{b. Minor Character}

Minor characters are unlikely to be used as a viewpoint character. Pope (2005:135) states that the minor characters appearances in the literary work will be brief and infrequent although that does not mean that they cannot shine whenever they are in the spotlight. Minor characters essentially two dimensional 
stereotypes, or flat character. The minor characters are comprised of all the other characters in the story whose are of lesser importance.

In other hand, Sutton (1971:9) divides characters in fiction can into four types. (a) Flat characters are characterized by one or two traits, they can be summed up in a sentence;(b) Round characters are complex and many sided, they might require an essay for full analysis;(c) Staticcharacter is a character who remain the same from the beginning of a work to the end while;(d) dynamic character exhibit some kind of change of attitude, of purpose, of behavior as the story progresses.

\section{a. Flat Character}

Flat characters are relatively simple, have a few dominant traits, and tend to be predictable. They are complex in temperament and motivation and represented with subtle particularity. Usually flat characters are minor (e.g., relatives, acquaintances, functionaries), although not all minor characters are necessarily flat (Sutton, 1971:9). Flat characters do not grow. They remain the same because they may be stupid or insensitively or lacking in knowledge or insight. They end where they begin and are static, not dynamic.

b. Round Character

Round character usually plays a major role in a story. They are often called the hero or heroine. Many main characters are anything but heroic, however, and it is therefore preferable to use the more neutral word protagonist. Sutton (1971:10) states that the protagonist is central to the action move against an antagonist, and exhibits the ability to adapt to new circumstances. Round character is usually a main character, and is developed over the course of the story. These characters have been fully developed by an author, physically, mentally, and emotionally, and are detailed enough to seem real.

\section{c. Static Character}

Static characters remain essentially the same throughout the film. The action does not have an important effect on their lives (as might generally be the case with the hero of an action or adventure film). Furthermore, Sutton (1971:10) 
states that static characters are almost essential to comedy and developing characters are essential to serious drama. In other words, a static character is a literary character that remains basically unchanged throughout a work.

d. Dynamic Character

A dynamic character is the one who changes significantly during the course of the story. Changes considered to qualify a character as dynamic include changes in sight or understanding, changes in commitment, and changes in values (Sutton, 1971:12). Changes in circumstances, even physical circumstance, do not apply unless they result in some change within the character itself. By that definition, the protagonist is nearly always a dynamic character.

\section{RESEARCH METHOD}

This study was conducted by using descriptive qualitative design. It required the writer to analyze the kinds of characterization of the main character in Gone Girl film and the most dominant of characteristic of her.The source of the data of this study wasGone Girl film. It was a 2014 American psychological thriller film directed by David Fincher and the adaption of Flynn's 2012 novel of the same name. The writer used a film script which is transcribed into sentences as the data.

The method of collecting data was documentary technique that proposed by Ary, et al, (2002). It is about collecting data by observing an event or setting: or documents of popular culture, such as books, films, and videos. In addition to that, 
technique in collecting data allows the writer to thoroughly collect the object of the study. Therefore, since the writer used descriptive qualitative design for this study, she required available data that were taken from a film script which suited to the method.

Moreover, referring to the method used to complete the analysis, the writer took a number of steps in order to response the two problem statements. The first step was downloading the film and the movie script as source of the data. The second step was transcribedthe film script into the written language, especially the utterances of Amy becausethe data were limited into her utterances as the main character. The third step was classifying the data which indicated to the characterization of Amy based on indirect characterization method by Burroway. The fourth step was finding the most dominant characteristic of Amy by counting the data using mathematic formula to get which characteristic the most appeared in the film.

\section{RESEARCH FINDINGS}

There were five characteristics of Amy found in the film. Those characteristics were; (1) intelligent, (2) perfectionist, (3) insecure, (4) liar, and (5) vengeful. The percentage of the data is provided by the table as follow:

Table 3.1The Percentage of Characteristics of Amy in Gone Girl Film

\begin{tabular}{cccc}
\hline No & Characteristics of Amy & Total Quotes & Percentage \\
\hline 1. & Intelligent & 7 & $17,94 \%$ \\
$\mathbf{2 .}$ & Perfectionist & 5 & $12,82 \%$ \\
$\mathbf{3 .}$ & Insecure & 11 & $28,20 \%$ \\
$\mathbf{4 .}$ & Liar & 13 & $33,33 \%$ \\
$\mathbf{5 .}$ & Vengeful & 3 & $7,69 \%$
\end{tabular}


Furthermore, all 39 quotes classifiedinto the five characteristics of Amy Elliot Dunne as the main character in the film, they were: (1) 7 quotes (17.94\%) Amy as intelligent, (2) 5 quotes (12.82\%) as perfectionist, (3) 11 quotes (28.20\%) as insecure, (4) 13 quotes (33.33\%) as liar, and (5) 3 quotes (7.69\%) as vengeful, the writer concluded that the most dominant characteristic of Amy has in the film is liar. The details of the analysis showed as follows:

a. Intelligent

Amy was a smart woman. She loved books and always being written journals. She was a daughter from two famous writers. As a child, she was the inspiration for her parents to create "Amazing Amy", a series of popular children's book. The book tells Amy as an amazing girl, smart, and has a perfect childhood. For her parents, she was the golden child who is brilliant and perfect.

Nick:"well, Amy, who are you?

Amy: "I write personality quizzes for magazines." (Gone Girl/00:04:41)

This was the dialogue between Amy and Nick when they first met in a party. This sentence revealed that Amy as a writer of a certain magazine. She wrote the personality quizzes part in the magazine. This showed that Amy as a smart and intelligent woman and has a good occupation.

\section{b. Perfectionist}

Amy was a perfectionist person and very changeable. She wanted other people being treated her like a queen as her parents did. Amy was growing up with the high standards of life. These high standards made Amy yearn to be perfect.

"He actually expected me to love him unconditionally. Then he dragged me, penniless, to the navel of this great country and found himself a newer, younger, bouncier, cool girl. You think I'd let him destroy me and end up happier than ever? No fucking way. He doesn't get to win." (Gone Girl/01:12:01) 
From Amy's quotation, it revealed that Amy as a perfectionist woman who wanted the perfect marriage relationship. She switched from one intense emotion to another very quickly often with angry outbursts.Amy thought she was not like an idiot woman who wanted to love her husband unconditionally, it was nonsense for her.

c. Insecure

Amy often felt insecure and paranoid. Because she as a perfectionist woman who wanted to have a perfect life and relationship, she often has an excessive afraid of feeling.

"Nick is happy to be home. But I don't know if he's happy I'm with him. I feel like something he loaded by mistake. Something to be jettisoned, if necessary.Something disposable. I feel like I could disappear." (Gone Girl/00:41:41)

This sentence revealed that Amy feels that Nick was not happy being live with her. She felt it getting worse when they move to Nick's house. Amy felt that she was abandoned by Nick.

d. Liar

Starting with her ego to making the plan of manipulation of her murder to push Nick to the jail, Amy has done some deceptions to reach her own goals.

Greta: "Hey, neighbor. It's been weeks since I had anyone decent next door."

Amy: "Well, I don't know how decent I feel."

Greta:" Well, as long as you don't own a python... and blast death metal at 4 AM...we're gonna be best friends."

Amy: "All right. Nice meeting you."

Greta: "I'm Greta."

Amy: "I'm Nancy."

Greta: "Are you going to the marina? I could use some creamer."

Amy: "Oh, I'm sorry. I can't. I've got work to do."

Greta: "All right. See you around!"

Amy: “You Will.”(Gone Girl/01:15:36)

The sentences were the dialogues between Amy with her new neighbor in her runaway place. Amy did not have desire to be friend with anyone at that scene. She just wanted to ignore her new neighbor, Greta. In her runaway mission 
she changed her identity and her appearance. She changed her name become Nancy. From Amy's quotation, she lied to her neighbor about her name.

e. Vengeful

Amy becamethe master at manipulator and madeup her own murder to trap Nick because of his cheating on her. Amy was a vengeful woman who ready took a serious risk. And she attempted to frame Nick for her murder to make it seem as though her husband, Nick killed her like a professional.

"My cute, charming,salt-of-the-earth, Missouri guy.He needed to learn.Grown-ups work for things.Grown-ups pay.Grown-ups suffer consequences." (Gone Girl/01:12:36)

This sentence showed that Amy as a vengeful person. She wanted to revenge to Nick her husband after all the bad things that Nick done to her. She thought Nick must get the consequences because his affair with other woman who be younger than Amy. Amy felt her marriage had been broken caused by Nick.

\section{DISCUSSION}

The findings of the study dealt with the characterizations and the most dominant characteristic of Amy as the main character in Gone Girl film.It revealed some important points that show the difference and the similarity from the previous studies that also focus on the similar subject matter.

The study by Faisal (2011) analyzed characterization trough personality traits of main character on Bruce Almighty movie. He found that Bruce as the main character was irritable or anger, complaining and blaming person, selfish, and jealous which was in contrary with this study found that Amy was intelligent, 
perfectionist,insecure, liar and vengeful. The most dominant characteristic of Amy was liar. The similarity found among the study was the character that analyzed was the antagonist character.

Fierro (2014) studied about characterization in the characters of Edgar Allan's poem and the novel by Fyodor Dostoyevsky analyzed more than one character. Different from this study, she examined the protagonist characters and found that the characters had personality disorder, they as antisocial who were self-centered individuals who pursue their plan with calculation and lack of empathy. Similar with the finding of this study, Amy as the main character also had a personality disorder beside her five main characteristics (intelligent, perfectionist, insecure, liar, and vengeful), she is an antisocial and psychopath. She did some manipulations and black mailing even killing people.

From the discussion, it revealed that characterization was the interesting matter which is used to analyzing the characteristics of characters in any literary works by some researchers in the world. The characterization research was not only useful for researches, but it gave contribution to the readers and peoples who enjoying and interested on literary works such novels, poems, and films.

\section{CONCLUSION AND SUGGESTION}

\section{A Conclusions}

The writer has finally deduced the conclusions to the research problem of this study. The conclusions were:

1. There were five kinds of Amy characteristics in the film, they are: (1) intelligent(17.94\%), (2) perfectionist(12.82\%), (3) insecure(28.20\%), (4) liar (33.33\%)and (5) vengeful(7.69\%).

2. The most dominant characteristic of Amy in the film was liar. Amy was a master manipulator, an expert at mind games, lying, blackmailing, change identity, and faking murder.

\section{B Suggestions}


Referring to the results of the study, there were some suggestions for:

1. The students who interested in learning the characterization methods, should know about the principles of the method itself in order to enrich their knowledge when learn about it. In analyzing the characterization of the characters, it is suggests for the students to learn about it deeper and understanding the different methods in it.

2. The readers coulduse the result of this study especially to the teaching and learning of characterization of character in literary work and can be used to develop and give inspiration for further study. This was believed to be able to reach the essence of education. 


\section{REFERENCES}

Ary, D., Jacobs, L.C., and Razavieh, A. 2002.Introduction to Research in Education. New York : Wadsworth Thomson Learning.

Aquino, J. (1976). Science Fiction as Literature.Washington D.C: National Education Association.

Bennett, A. and Royle, N. (2004).An Introduction to Literature, Criticism and Theory.Edinburgh: Pearson Education.

Burroway, J. (2000). Writing Fiction: A Guide to Narrative Craft.London: Longman.

Charters, A. (2011).The Story and Its Written: An Introduction to Short Fiction. New York: Bedford.

Faisal. (2011). Analysis of Main Character in Bruce Almighty Movie Viewed from Personality Traits Theory by Costa and McCrae.Jakarta. State Islamic UniversitySyarifHidayatullah. http://repository.uinjkt.ac.id/3642. [ $3^{\text {rd }}$ June 2016]

[Online].Retrieved:

Fierro, D. S. (2014). "The Psychopath in Dostoyevsky and Poe: A Psychological Insight of A Killer".Journal of Artistic Creation and Literary Research (JACLR), Vol.2(1), 37-50.

Klarer, M. (2004).An Introduction to Literature Studies; (Second Edition) London: Routledge.

Pope, R. (2005). Creativity: Theory, History, Practice. New York: Routledge.

Sutton, L. M. (1971). Journey: An Introduction to Literature. Boston: Holbrook Press.

Mlillon, T., and Everly, G. S.(1985). Personality Disorder and Its Disorders. New York: John Wiley \& Sons.

Millon, T., Grossman, S., Millon, C., Meagher, S., and Ramnath, R. (2004). Personality Disorders in Modern Life. New Jersey: John Wiley \& Sons. 